\title{
Carbonation, cementation, and stabilization of ultramafic mine tailings through microbial $\mathrm{CO}_{2}$ generation
}

\author{
JUSTIN A. LOCKHART, IAN M. POWER, CARLOS \\ PAULO, HANNAH LONG AND AMANDA R. STUBBS
}

Trent University

Presenting Author: justinlockhart@trentu.ca

Tailings dam failures can cause devastation to the environment, loss of human life, and require expensive remediation [1]. A promising approach for de-risking brucitebearing ultramafic tailings is in situ cementation via carbon dioxide $\left(\mathrm{CO}_{2}\right)$ mineralization, which also sequesters this greenhouse gas within carbonate minerals [2,3]. In cylindrical test experiments (up to 10 weeks), brucite $\left[\mathrm{Mg}(\mathrm{OH})_{2}\right]$ carbonation was accelerated using microbially-generated $\mathrm{CO}_{2}$ from waste organics placed in association with cylinders inside closed containers. $\mathrm{CO}_{2}$ concentrations rapidly increased and rivaled that of flue gas (up to $19 \%$ ). The abundance of brucite (2-10 wt.\%) had the greatest influence on overall $\mathrm{CO}_{2}$ sequestration and cementation of tailings as evidenced by the increase in total inorganic carbon (TIC; $+0.17-0.84 \%$ ). Brucite consumption ranged from $64-84 \%$ of its initial abundance and was mainly affected by water availability. Higher moisture contents (40-80\% saturation) and finer grain sizes (e.g., claysilt) that allowed for redistribution of water resulted in greater brucite carbonation. Furthermore, pore clogging and surface passivation by Mg-carbonates may have slowed the rate of brucite carbonation over 10 weeks. Unconfined compressive strength increased linearly with TIC [UCS $(\mathrm{MPa})=9.5 \mathrm{x}$ TIC increase $(\%)-1.6 ; \mathrm{R}^{2}=0.87$, reaching $6.9 \mathrm{MPa}$ in cylinders with 10 wt. $\%$ brucite. Ongoing experiments (up to 40 weeks) are utilizing fine-grained organics within cylinders of brucitebearing tailings to better mimic the amendment of organics during tailings deposition. Preliminary results suggest that over 10 weeks, adding $1 \mathrm{wt} . \%$ waste organics more than doubled the UCS of tailings from 0.24 to $0.51 \mathrm{MPa}$, yet greater abundances of organics (2-10 wt.\%) moderately diminished UCS (0.17-0.37 $\mathrm{MPa})$. Our study demonstrates the potential for stabilizing brucite-bearing mine tailings through in situ cementation while sequestering $\mathrm{CO}_{2}$. [1] Dong et al. (2020), J. Clean. Prod. 269, 122270. [2] Vanderzee et al. (2018), Geosci. BC Annu. Rep., 109-112. [3] Wilson et al. (2014), Int. J. Greenh. Gas Control 25, 121-140. 